in vivo $32: 1081-1088(2018)$

doi:10.21873/invivo.11349

\title{
Antitumor Activity of Betulinic Acid and Betulin in Canine Cancer Cell Lines
}

\author{
JING ZHAO $^{1^{*}}$, RONGFANG LI ${ }^{1 *}$, ALEKSANDRA PAWLAK ${ }^{2}$, MARTA HENKLEWSKA $^{2}$, \\ ANGELIKA SYSAK ${ }^{2}$, LIXIN WEN ${ }^{1}$, JIN-E YI $^{1}$ and BOŻENA OBMIŃSKA-MRUKOWICZ ${ }^{2}$ \\ ${ }^{1}$ College of Veterinary Medicine, Hunan Agricultural University, Changsha City, P.R. China; \\ ${ }^{2}$ Department of Pharmacology and Toxicology, Faculty of Veterinary Medicine, \\ Wrocław University of Environmental and Life Sciences, Wrocław, Poland
}

\begin{abstract}
Background/Aim: Betulinic acid (BA) and betulin (BT) exhibit a variety of pharmacological properties including anti-cancer, anti-inflammatory and anti-oxidant ones. Canine lymphoma and osteosarcoma have a high mortality rate and need more effective therapeutic approaches. In this study, the anti-proliferative and pro-apoptotic effects of $B A$ and $B T$ were investigated in canine T-cell lymphoma (CL-1), canine B-cell lymphoma (CLBL-1) and canine osteosarcoma (D-17) cell lines. Materials and Methods: The cultured cells were treated with several concentrations of BA or BT for 24,48 and $72 h$, and cell proliferation was assessed by the MTT assay. Cell apoptotic rate and cell cycle were analyzed using flow cytometry. Results: Anti-proliferative effect of BT and BA was concentration- and time-dependent. Moreover, BA and BT arrested cell cycle in $S$ phase in CL-1 and D-17 cells, and in $G_{0} / G_{1}$ phase in CLBL-1 cells. Conclusion: Both compounds showed an antitumor activity, and the effects of BA were stronger than that of $B T$.
\end{abstract}

Canine non-Hodgkin's lymphoma (NHL) shares some molecular and clinical features with human NHL (1-3). Malignant canine lymphoma and osteosarcoma are common

This article is freely accessible online.

*These Authors contributed equally to this work.

Correspondence to: Jin-E Yi, College of Veterinary Medicine, Hunan Agricultural University, Changsha City, 410128, P.R. China. Tel: +86 07314618001, Fax: +86 07314611473, e-mail: yijine@gmail.com; Bożena Obmińska-Mrukowicz, Department of Pharmacology and Toxicology, Faculty of Veterinary Medicine, Wrocław University of Environmental and Life Sciences, C.K. Norwida 31, 50-375, Wrocław, Poland. Tel: +48 713205403, Fax: +48 713205455, e-mail: b.mrukowicz@gmail.com

Key Words: Betulin acid, betulin, antiproliferative activity, apoptosis, cell cycle, canine lymphoma, canine osteosarcoma. and severe disorders, and their incidence is increasing rapidly $(3,4)$. Traditionally, surgery, chemotherapy and radiation have been the main treatments but they are associated with serious side-effects and long treatment cycle. Still, the survival of dogs with lymphoma remains brief $10 \%$ survival rate ranges from 12 to 24 months (5). Therefore, new drugs and therapies with lower toxicity and higher anticancer activity are being constantly looked for.

Herbal and natural products with antitumor activities are used in cancer treatment (6). Pentacyclic lupane-type triterpenoids are abundant in fruits, acuminatissima leaves, white birch bark, and are popular in dietary supplements (7, 8 ). Betulinic acid (3 $\beta$-hydroxy-lup-20(29)-en-28-oic acid, BA, Figure 1A) and betulin (3ß-lup-20(29)-en-3,28-diol, $\mathrm{BT}$, Figure 1B), belong to pentacyclic triterpenes commonly found in the bark of birch trees (Betula L.). BA and BT have a variety of beneficial activities, e.g. antiviral, anti-inflammatory, anti-malarial, anti-HIV and anti-cancer effects (9-13).

BA and BT selectively affect various tumor cells and are poorly toxic to normal cells (14). These two compounds inhibit proliferation of over 20 different cancer cell lines, including melanoma, lung cancer, and lymphoma cells. Proposed mechanisms of their anti-tumor action include induction of apoptosis, inhibition of cell viability, antiangiogenesis, cell-cycle arrest, and inhibition of invasion/migration (15).

Normally, cell proliferation and cell death are a result of a dynamic balance. Tumor formation is caused by excessive proliferation and differentiation of cells or apoptosis disturbances. Therefore, inducing apoptosis of tumor cells is a useful cancer treatment. Triterpenoids may selectively inhibit human DNA topoisomerases (16), important enzymes of the cell cycle, and thus exert anti-cancer effects (17). The aim of this study was to investigate the anti-tumor effects of BA or BT and compare their therapeutic potential in canine T-cell lymphoma (CL-1), canine B-cell lymphoma (CLBL-1) and canine osteosarcoma (D-17) cell line. 
A

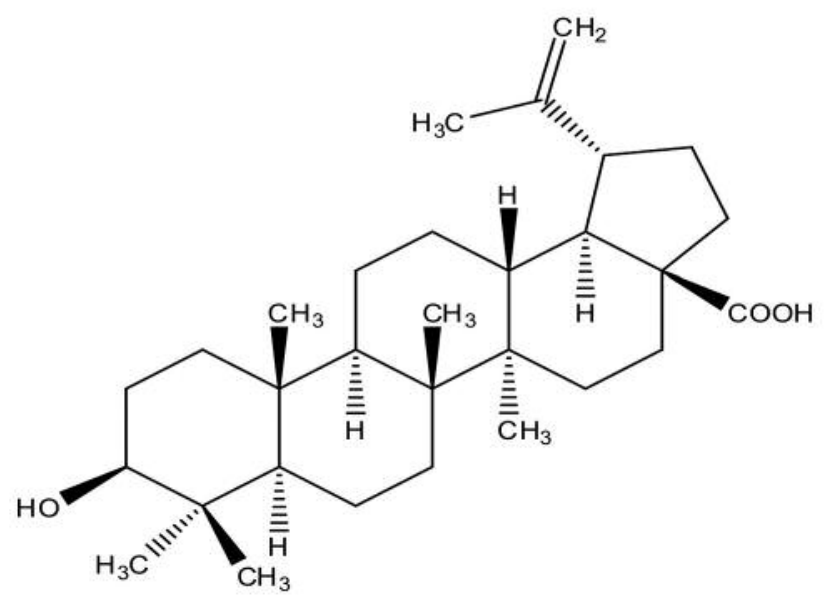

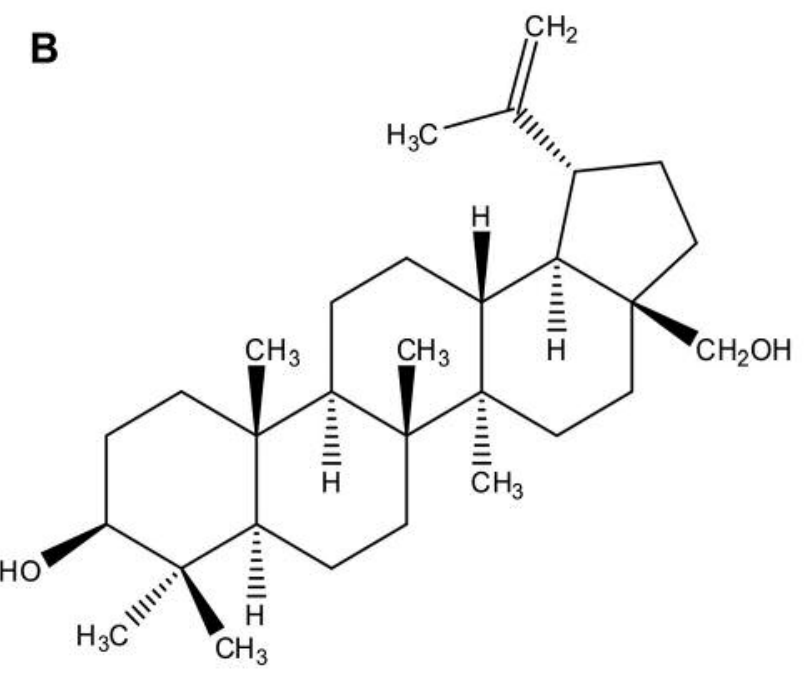

Figure 1. Chemical structure of $B A(A)$ and $B T(B)$.

\section{Materials and Methods}

Chemicals and reagents. BA, BT with a purity of $\geq 98 \%$ by HPLC, fetal bovine serum (FBS), penicillin and streptomycin solution, L-glutamine, ribonuclease (RNase) A and propidium iodide (PI) were purchased from Sigma-Aldrich (Steinheim, Germany). Annexin V FITC was bought from Immunostep (Salamanca, Spain). Dimethyl sulphoxide (DMSO) was acquired from POCh (Gliwice, Poland). Phosphate buffered saline (PBS) and RPMI 1640 culture medium were obtained from the Institute of Immunology and Experimental Therapy (Wroclaw, Poland).

Cell lines and cultures. Different canine cancer cell lines were used in this study. The lymphoma cell lines included CL-1 (T-cell lymphoma) and CLBL-1 (B-cell lymphoma cell line). CL-1 cell line was provided by Yusuhito Fujino and Hajime Tsujimoto from the University of Tokyo, Department of Veterinary Internal Medicine (18), while CLBL-1 cell was obtained from Barbara C. Ruetgen, Department of Pathobiology, Institute of Immunology at the University of Veterinary Medicine in Vienna (19). Canine osteosarcoma cell line (D-17) was obtained from ATCC. CL-1, CLBL-1 and D17 cell lines were grown in RPMI 1640 culture medium with $1 \%$ L-glutamine, $1 \%$ penicillin and streptomycin, and $10 \%$ heat-inactivated FBS. The culture was maintained under 5\% $\mathrm{CO}_{2}$ at $37^{\circ} \mathrm{C}$. The cells were cultured in $75 \mathrm{~cm}^{2}$ flasks (Corning, USA) with fresh medium replaced every two days.

Drug preparation. BA and BT were dissolved in dimethyl sulfoxide (DMSO) to prepare $20 \mathrm{mM}$ stock solutions, and DMSO concentration was below $0.2 \%$ in all samples.

MTT assay. Cell proliferation was measured by MTT assay (20). Briefly, cells at a density of $1 \times 10^{4} /$ well (CL-1, CLBL-1) and $1.5 \times 10^{3} /$ well (D-17) were seeded in a 96-well-plate (TPP, Trasadingen, Switzerland) and pre-incubated at $37^{\circ} \mathrm{C}$ under $5 \% \mathrm{CO}_{2}$ for $24 \mathrm{~h}$. Then, various concentrations of BA or BT $(1,5,10,15$, $20,25,30$ and $40 \mu \mathrm{M})$ were added and the samples were further incubated for $24 \mathrm{~h}, 48 \mathrm{~h}$ and $72 \mathrm{~h}$. After incubation, $20 \mu \mathrm{l}$ of 5 $\mathrm{mg} / \mathrm{ml}$ MTT were added to each well and the samples were left for $4 \mathrm{~h}$. After this time $80 \mu \mathrm{l}$ of a lysis buffer $(225 \mathrm{ml} \mathrm{DMF}, 67.5 \mathrm{~g}$ SDS, $275 \mathrm{ml}$ distilled water) were added. The absorbance of the culture media in the wells was measured after $24 \mathrm{~h}$ with a microplate reader (Elx 800 , BioTek, USA) at $570 \mathrm{~nm}$. Cell viability was calculated according to the following formula:

$\%=[$ (average absorbance for the treated group - average absorbance for the background)/(average absorbance for the control group - average absorbance for the background)]*100. $\mathrm{IC}_{50}$ for $\mathrm{BA}$ and $\mathrm{BT}$ was calculated as a mean concentration inhibiting cell proliferation by $50 \%$ in three independent experiments.

Analysis of cell apoptosis. Cell apoptosis was determined by flow cytometry using annexin V-FITC and PI staining. Briefly, CL-1 and D-17 cells were seeded in 24-well cell culture plates (TPP, Trasadingen, Switzerland) at a density of $1 \times 10^{5}$ and $8 \times 10^{4}$ cells per well respectively, and CLBL-1 cells were seeded in 96-wellplates at the density of $1 \times 10^{4}$ cells per well. After $24 \mathrm{~h}$ incubation, the cells were treated with BA or BT for $24 \mathrm{~h}$. Then, they were washed twice with cold PBS and suspended in a binding buffer containing annexin V-FITC for $10 \mathrm{~min}$ at room temperature. After the incubation, PI $(1 \mu \mathrm{g} / \mathrm{ml})$ solution was added and the cells were analyzed using a flow cytometer (FACS Calibur, BD Biosciences, San Jose, USA). CellQuest 3.lf. software (Becton Dickinson, San Jose, USA) was used for data analysis.

Cell-cycle analysis. CL-1 and CLBL-1 cells were seeded in 12-well plates (TPP, Trasadingen, Switzerland) at the density of $6 \times 10^{5}$ cells/well and D17 cells were seeded in 6-well plates (TPP, Trasadingen, Switzerland) at the density of $4 \times 10^{5}$ cells/well and 

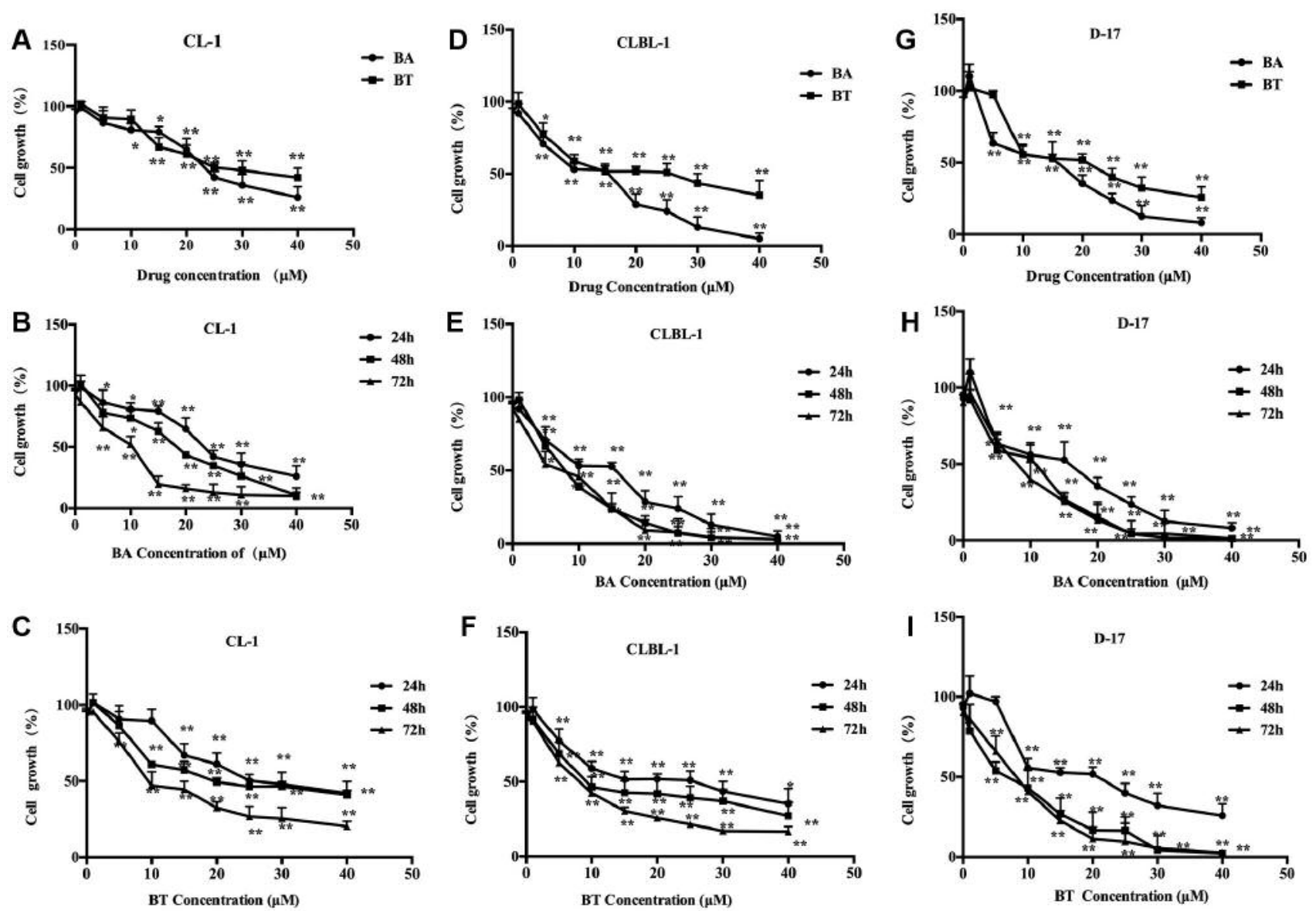

Figure 2. Time- and concentration-dependent inhibition of proliferation of the canine cancer cell lines by BA and BT. (A) proliferation of CL-1 cells treated with different concentrations of BA and BT for $24 \mathrm{~h} ;(B)$ proliferation of BA-treated CL-1 cells after different treatment duration; (C) proliferation of BT-treated CL-1 cells after different treatment duration; (D) proliferation of CLBL-1 cells treated with different concentrations of $B A$ and BT for $24 h ;(E)$ proliferation of BA-treated CLBL-1 cells after different treatment duration; $(F)$ proliferation of BT-treated CLBL-1 cells after different treatment duration; $(G)$ proliferation of D-17 cells treated with different concentrations of BA and BT for 24 h; $(H)$ proliferation of BA-treated D-17 cells after different treatment duration; (I) proliferation of BT-treated D-17 cells after different treatment duration. Data are shown as the mean $\pm S D$, Analysis of variance (ANOVA): *p<0.05,**p<0.01, compared to control.

incubated at $37^{\circ} \mathrm{C}$ under $5 \% \mathrm{CO}_{2}$ for $24 \mathrm{~h}$. Then, the cells were treated with BA or BT for $24 \mathrm{~h}$. After incubation, they were harvested and washed twice with cold PBS. Next, they were fixed in cold $70 \%$ ethanol and incubated overnight at $4^{\circ} \mathrm{C}$. After washing with cold PBS, the cells were re-suspended in cold PBS containing RNase $0.5 \mathrm{mg} / \mathrm{ml}$, incubated for $1 \mathrm{~h}$ and stained with PI (final concentration $10 \mu \mathrm{g} / \mathrm{ml}$ ). The cells were analyzed by a flow cytometer (FACS Calibur, BD Biosciences, San Jose, USA) and CellQuest 3.lf. software. The presented results are means from three independent experiments.

Statistical analysis. All the data are expressed as mean values \pm standard deviations from three independent experiments. The $p$-value of $<0.05$ was considered significant, and data for multiple treatment groups were analyzed using Tukey's post-test and ANOVA with SPSS 16.0 statistical software.

\section{Results}

$B A$ and BT inhibited proliferation of CL-1, CLBL-1 and D-17 cells. To investigate the effect of BA and BT on the canine cancer cell lines, the cells were treated with increasing concentrations of BA and BT for $24 \mathrm{~h}$ as shown in Figure 2A, $\mathrm{D}$, and G. Cell proliferation decreased in a concentrationdependent manner in all three cell lines, and $\mathrm{IC}_{50}$ for BA and BT was $23.50 \mu \mathrm{M}$ and $27 \mu \mathrm{M}$ for CL-1, 18.2 $\mu \mathrm{M}$ and $28.9 \mu \mathrm{M}$ for CLBL-1, and $18.59 \mu \mathrm{M}$ and $22.73 \mu \mathrm{M}$ for D-17 line, respectively. These results suggest that $\mathrm{BA}$ was more effective than BT in inhibiting the growth of cancer cells. CL-1 cell proliferation after 24,48 and $72 \mathrm{~h}$ exposure to $40 \mu \mathrm{M}$ BA or $40 \mu \mathrm{M}$ BT was reduced by $73.95 \pm 8.60 \%$ and $57.98 \pm 7.76 \%$, 
A
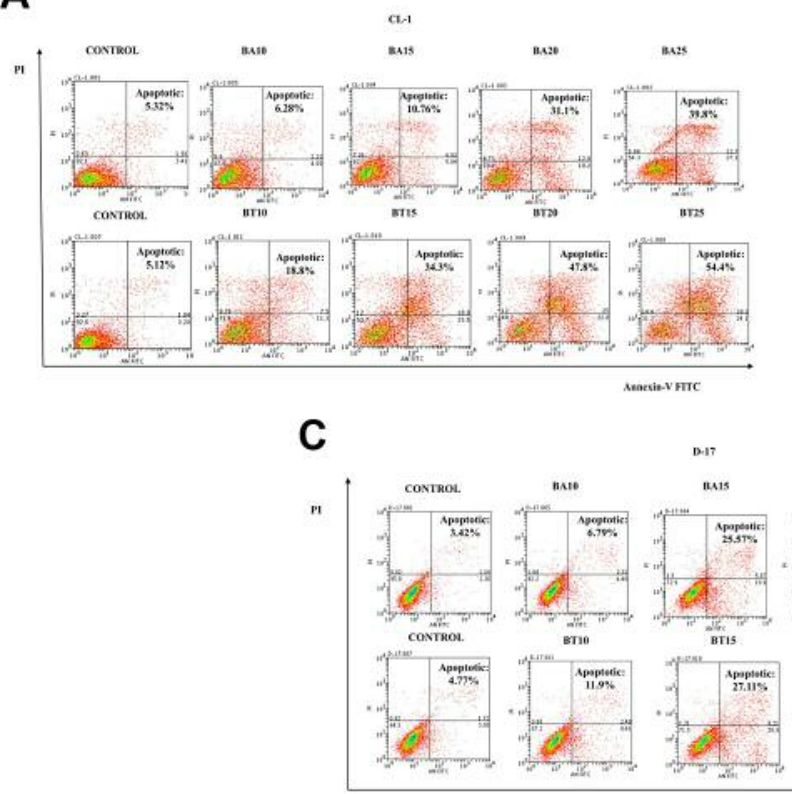

D

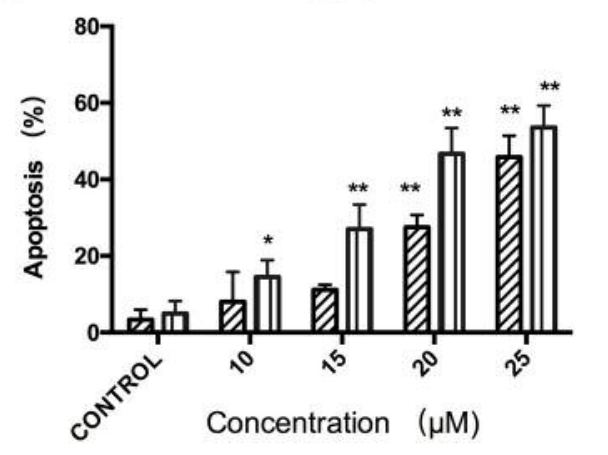

B

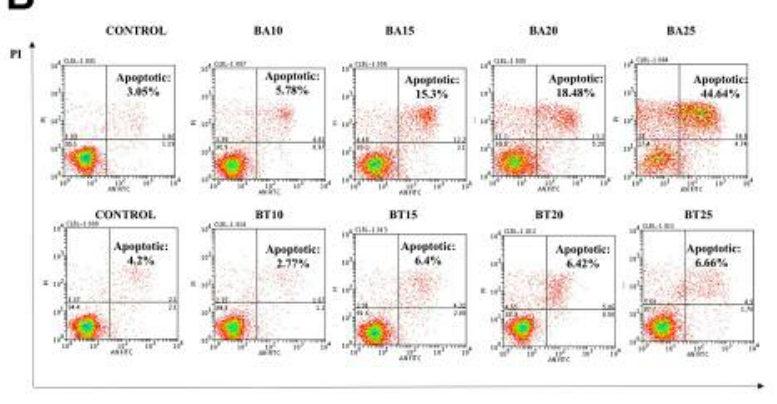

Aanesia V-FITC
Figure 3. Effect of BA or BT on CL-1,CLBL-1, D-17 cell apoptosis. Flow cytometric analysis of the apoptosis of $C L-1$ (A), CLBL-1 (B), $D-17(C)$ cells treated with BA or BT for $24 h$ and stained with annexin V-FITC/PI. Quantitative analysis of the percentage of CL-1 (D), CLBL-1 (E), D-17 (F) cell apoptosis. Data are shown as the mean $\pm S D$, Analysis of variance (ANOVA): *, $p<0.05, * *, p<0.01$, compared to control.
E

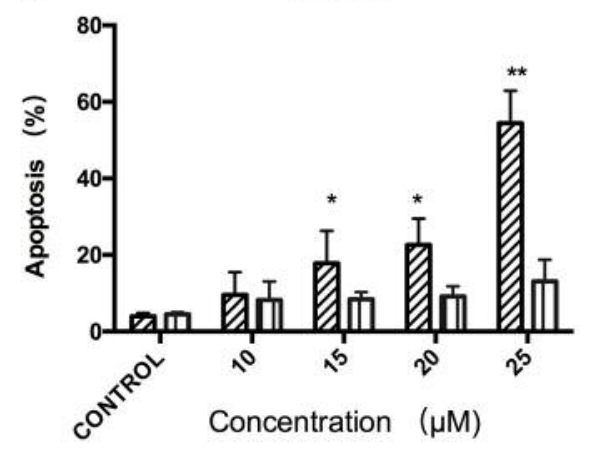

$\mathbf{F}$

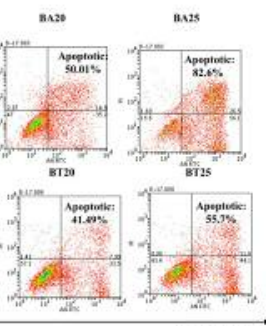

[DA m BT

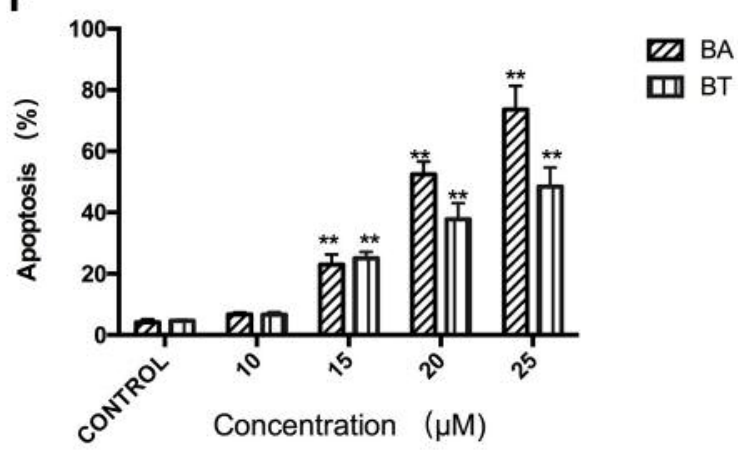

$89.61 \pm 6.15 \%$ and $59.06 \pm 3.03 \%, 90.24 \pm 3.21 \%$ and $79 \pm 3.38 \%$, respectively (Figure $2 \mathrm{~B}$ and $\mathrm{C}$ ). Under the same condition, CLBL-1 growth was reduced by $95.43 \pm 4.45 \%$ and $64.83 \pm 10.2 \%, 97.23 \pm 1.4 \%$ and $72.91 \pm 9.41 \%, 97.01 \pm 1.86 \%$ and $83.39 \pm 3.42 \%$, respectively (Figure $2 \mathrm{E}$ and F), D-17 cell proliferation was inhibited by $91.83 \pm 3.49 \%$ and $74.20 \pm 7.31 \%$, $98.70 \pm 0.62 \%$ and $97.69 \pm 0.64, \quad 98.61 \pm 0.46 \%$ and $97.18 \pm 1.15 \%$, respectively (Figure $2 \mathrm{H}$ and I). These results 
show that both compounds inhibited cell proliferation in a time-dependent manner, and BA was more effective in all three cell lines.

$B A$ and BT induced CL-1,CLBL-1, D-17 cells apoptosis. The effects of BA and BT on cell apoptosis were analyzed by flow cytometry using annexin-V and PI staining. The apoptotic cells were presented as a summary of all annexin V-FITC positive cells. BA and BT induced CL-1 and D-17 cell apoptosis in a concentration-dependent manner. BA was more potent in inducing apoptosis in CLBL-1 than BT, even at high BT concentrations (Figure 3).

After $24 \mathrm{~h}$ treatment with $25 \mu \mathrm{M}$ BA or $25 \mu \mathrm{M}$ BT, the percentage of apoptotic cells was $45.8 \pm 4.6 \%$ and $53.5 \pm 4.7 \%$ in CL-1 cell line (Figure $3 \mathrm{~A}$ and D), and $73.8 \pm 9.3 \%$ and $52.8 \pm 8.8 \%$ in D-17 cell line, respectively (Figure $3 \mathrm{C}$ and F). The apoptosis rate in CLBL-1 cells treated with $25 \mu \mathrm{M}$ BA or $25 \mu \mathrm{M}$ BT were $51.41 \pm 8.48 \%$ and $13.08 \pm 5.66 \%$, respectively (Figure $3 \mathrm{~B}$ and $\mathrm{E}$ ). Summing up, BA and BT triggered apoptosis, which confirmed the results of the MTT assay in CL-1 and D-17 cell lines.

Effects of BA and BT on the cell cycle in CL-1,CLBL-1, and $D-17$ cells. The effects of BA and BT on the cell cycle were analyzed by flow cytometry using PI staining. BA and BT treatment resulted in a significant cell cycle arrest. BA and BT altered the cell cycle phase distribution in CLBL-1 cells and significantly increased the number of cells in $G_{0} / G_{1}$ phase. As shown in Figure $4, \mathrm{G}_{0} / \mathrm{G}_{1}$ phase was severely limited in CL-1 and D-17 cells treated with BA and BT, while both compounds at $10 \mu \mathrm{M}$ significantly increased the number of cells in $\mathrm{S}$ phase.

The effects of BA and BT concentrations on individual phases of the cell cycle were analyzed and similar effects were found in CL-1 and D17 cells (Tables I and II). Incubation with $10 \mu \mathrm{M}$ BA and BT altered the cell cycle, as the percentage of cells in $\mathrm{S}$ phase increased from $9.41 \pm 1.04 \%$ in control to $18.3 \pm 1.06 \%$ and $21.03 \pm 2.29 \%$ for CL-1; from $10.28 \pm 2.13 \%$ in control to $15.5 \pm 1.38 \%$ and $18.1 \pm 4.1 \%$ for $\mathrm{D}-17$. The response of CLBL-1 was unique, as the cells were arrested in $\mathrm{G}_{0} / \mathrm{G}_{1}$ phase. In this cell line, $10 \mu \mathrm{M}$ BA and $15 \mu \mathrm{M}$ BT significantly increased the percentage of cells in $\mathrm{G}_{0} / \mathrm{G}_{1}$, from $38.80 \pm 2.95 \%$ in control to $45.06 \pm 1.18 \%$ and $48.70 \pm 4.25 \%$, respectively (Table III).

\section{Discussion}

The anti-tumor activity of BA and BT in three canine cell lines derived from different cell lineages was evaluated. In all three cell lines, BA and BT showed significant anti-tumor effects, such as decreasing cell proliferation, inducing cell apoptosis, and arresting cell cycle. The study confirmed potent inhibitory effects of BA and BT on cell proliferation,
Table I. Effect of BA or BT on cell-cycle progression in CL-1 cells. Quantitative analysis of the percentage of cell cycle distribution in $C L-1$ cells. Data are shown as the mean $\pm S D$, Analysis of variance (ANOVA): ${ }^{*} p<0.05,{ }^{*} p<0.01$, compared to control.

\begin{tabular}{lrlll}
\hline CL-1 & Sub- $\mathrm{G}_{0}$ & \multicolumn{1}{c}{$\mathrm{G}_{0}$} & $\mathrm{~S}$ & $\mathrm{G}_{2} / \mathrm{M}$ \\
\hline CONTROL & 6.81 & 57.27 & 9.41 & 20.63 \\
BA10 & 6.80 & 51.53 & $18.3^{* *}$ & 16.13 \\
BA15 & 8.50 & $49.5^{*}$ & 15.30 & 18.50 \\
BT10 & 8.60 & $41.43^{* *}$ & $21.03^{* *}$ & 18.67 \\
BT15 & 10.45 & $40.8^{* *}$ & $19.33^{* *}$ & 19.80 \\
\hline
\end{tabular}

Table II. Effect of BA or BT on cell-cycle progression in D-17 cells. Quantitative analysis of the percentage of cell cycle distribution in $D-17$. Data are shown as the mean $\pm S D$, Analysis of variance (ANOVA): $* p<0.05, * * p<0.01$, compared to control.

\begin{tabular}{lclll}
\hline D17 & Sub- $\mathrm{G}_{0}$ & \multicolumn{1}{c}{$\mathrm{G}_{0}$} & \multicolumn{1}{c}{$\mathrm{S}$} & $\mathrm{G}_{2} / \mathrm{M}$ \\
\hline CONTROL & 2.50 & 52.40 & 10.28 & 25.60 \\
BA10 & 4.17 & 47.47 & $15.5^{*}$ & 22.70 \\
BA15 & 5.81 & $44.23^{* *}$ & $17.26^{*}$ & 22.50 \\
BT10 & 3.91 & $43.6^{* *}$ & $18.1^{* *}$ & 23.97 \\
BT15 & 3.67 & $41.63^{* *}$ & $17^{*}$ & 24.63 \\
\hline
\end{tabular}

Table III. Effect of BA or BT on cell-cycle progression in CLBL-1 cells. Quantitative analysis of the percentage of cell cycle distribution in CLBL-1 cells. Data are shown as the mean $\pm S D$, Analysis of variance (ANOVA): ${ }^{*} p<0.05, * * p<0.01$, compared with control.

\begin{tabular}{lclll}
\hline CLBL-1 & Sub-G $_{0}$ & \multicolumn{1}{c}{$\mathrm{G}_{0}$} & \multicolumn{1}{c}{$\mathrm{S}$} & $\mathrm{G}_{2} / \mathrm{M}$ \\
\hline CONTROL & 3.17 & 38.50 & 23.67 & 26.47 \\
BA10 & 4.63 & $45.07^{* *}$ & $17.03^{* *}$ & 23.20 \\
BA15 & 5.92 & 41.57 & 19.43 & 22.93 \\
BT10 & 3.15 & $44.5^{*}$ & $18.07^{*}$ & 24.83 \\
BT15 & 4.46 & $48.7^{* *}$ & $17.77^{*}$ & 22.37 \\
\hline
\end{tabular}

as indicated by decreased cell growth. BA and BT were investigated in a broad range of malignant cell lines and showed concentration-dependent effects on human melanoma cells, with a more pronounced response to BA (21). BA and BT exert anti-cancer and cytotoxic activity in human carcinoma of mouth (KB), human melanoma cells (Mel-2) and several neuroblastoma cell lines (SKNSH, IMR5, NBL-S, NBAS5, LAN-5) (22-23). Besides, BA and BT inhibit growth of other neoplastic cell lines (e.g. ovarian cancer, lung cancer, and cervical cancer) $(24,25)$.

In this study, BA and BT significantly inhibited cell growth, which is consistent with the literature (25). Cell 
proliferation after treatment with $20 \mu \mathrm{M}$ BA or BT was significantly limited: to $35.26 \pm 9.22 \%$ (BA) and $38.83 \pm 7.36 \%$ (BT) in CL-1 line, $71.32 \pm 7.44 \%$ (BA) and $48.23 \pm 3.37 \%$ (BT) in CLBL-1 line, and to $64.53 \pm 5.83 \%$ (BA) and $48.15 \pm 4.33 \%$ (BT) in D-17 line. BA was a more potent inhibitor than BT in all three cell lines. The anti-tumor effects of BA and BT were to some extent related to inhibited cell proliferation. Additionally, CLBL-1 line was the most sensitive to $\mathrm{BA}$ (the lowest $\mathrm{IC}_{50}$ for $\mathrm{BA}$ in all three cell lines), which was concurrent with previous studies (2628). It was suggested that B-cell lymphoma may be more sensitive to BA-based treatments.

This study indicated that the anti-proliferative effect of BA and BT was related to apoptosis. Both compounds exerted similar concentration-dependent inhibitory effects on cell proliferation and induced apoptosis. Large number of studies showed that BA and BT enhanced cell apoptosis in melanoma and human neuroectodermal cancer cells. Compared to BT, BA triggered stronger cytotoxic and apoptotic effects in different cancer cells (29-35). For example, 23-hydroxy BA induced cell apoptosis in a concentration-dependent manner in hepatocellular carcinoma cells (21), and BA had similar effects in human breast cancer cells (36). In our study, 24-h treatment with BA or BT resulted in similar pro-apoptotic effects in CL-1 and D-17 cell lines. At the same time, $25 \mu \mathrm{M}$ BA induced $51.41 \pm 8.48 \%$ cell apoptosis, which was less than the results of the MTT assay in CLBL-1 cell line. BT also inhibited proliferation to a much higher degree than it induced apoptosis, which suggests a different mode of action than for BA. Apoptosis induction requires higher concentration of the compound, therefore lower concentration of BT strongly inhibited proliferation but was too low to trigger apoptosis. This is consistent with another study, in which arsenic trioxide at low concentration inhibited cell proliferation and altered DNA content in hepatic carcinoma cells but did not induce any substantial apoptosis related changes in cell morphology and biochemistry (37).

The occurrence and development of cancer is associated with cell cycle, and DNA topoisomerases play a critical role in this process, as well as in transcription, recombination and chromosome segregation during mitosis (16). Several studies reported that triterpenoids could selectively inhibit human DNA topoisomerases (17), and BA and BT belong to the pentacyclictriterpenoids that induce tumor cell apoptosis partly by inhibition of DNA topoisomerase.

The growth of tumor cells may be inhibited at any phase of the cell cycle, which results in cell cycle arrest. For example, oleanolic acid (OA), which belongs to pentacyclictriterpenes, inhibits osteosarcoma cells MG63 and Saoa-2 and arrests a large number of cells in $\mathrm{G}_{0} / \mathrm{G}_{1}$ phase (38). Several studies indicated that OA could inhibit cell proliferation by damaging the active site of topoisomerases in cancer cells. A possible mechanism of
OA action involves inhibition of DNA synthesis and arresting the cancer cells in S phase (39). BA and BT are capable of altering cell cycle in human melanoma cell line, lung cell line and breast cancer cell line (24). BA induces cell cycle arrest in $G_{0} / G_{1}$ phase in human cervical cancer (Hela) cells and breast cancer $(6,28)$. BA may arrest MCF-7 cells and human cervical cancer cells in $G_{0} / G_{1}$ phase, potentially by increasing the expression of p53 and p21 or altering protein expression of related signaling pathways (mitochondria transduction pathway, PI3K/Akt, NF-kB signaling pathway) (40-42). Our study demonstrated a significant alteration of the cell cycle following BA and BT treatment. Both compounds considerably lowered the percentage of CL- 1 and $\mathrm{D}-17$ cells in $\mathrm{G}_{0} / \mathrm{G}_{1}$ phase and increased the percentage of cells in $\mathrm{S}$ phase, which indicated cell cycle arrest in this phase. In CLBL-1 cell line, a huge increase in the percentage of cells in $G_{0} / G_{1}$ phase indicated cell cycle arrest in this phase. Thus, BA and BT exert anticancer effects in canine cancer cells mainly through inhibition of topoisomerase expression and alteration of protein expression in related signaling pathways. BA or BT induce apoptosis and cell cycle arrest through different mechanisms in different types of tumor cells.

\section{Conclusion}

This study demonstrated anti-cancer activity of BA and BT in CL-1, CLBL-1, and D-17 cell lines. BA was more potent in inducing cell death in all tested canine cancer cell lines, but the underlying mechanisms need further investigation.

\section{Conflicts of Interest}

The Authors declare that they have no conflict of interest in this study and paper.

\section{Acknowledgements}

The Authors wish to thank B.C. Ruetgen (Institute of Immunology, Department of Pathobiology, University of Veterinary Medicine in Vienna) for providing CLBL-1 cell line, and Y. Fujino and H. Tsujimoto (University of Tokyo, Department of Veterinary Internal Medicine) for providing the CL-1 cell line. The Authors are grateful for the financial support from the National Key Research and Development Program of China (No. 2016YFD0501209) and Department of Education of Hunan Province, China (Key project No.17A098). Publication was supported by Wrocław Centre of Biotechnology, programme: the Leading National Research Centre (KNOW) for years 2014-2018

\section{References}

1 Kojima K, Fujino Y, Gotokoshino Y, Ohno K and Tsujimoto H: Analyses on activation of NF-kB and effect of bortezomib in canine neoplastic lymphoid cell lines. J Vet Med Sci 75(6): 727731, 2013. 
2 Breen M and Modiano JF: Evolutionarily conserved cytogenetic changes in hematological malignancies of dogs and humans man and his best friend share more than companionship. Chromosome Res 16(1): 145-154, 2008.

3 Marconato L, Gelain ME and Comazzi S: The dog as a possible animal model for human non-Hodgkin lymphoma: a review. Hematol Oncol 31(1): 1-9, 2013.

4 Merlo DF, Rossi L, Pellegrino C, Ceppi M, Cardellino U, Capurro C, Ratto A, Sambucco PL, Sestito V, Tanara G and Bocchini V: Cancer incidence in pet dogs: findings of the animal tumor registry of Genoa, Italy. J Vet Intern Med 22(4): 976-984, 2008 .

5 Watanabe MA, Amarante MK and Conti BJ: Cytotoxic constituents of propolis inducing anticancer effects: a review. J Pharm Pharmacol 63(11): 1378-1386, 2011.

6 Luo R, Fang D, Chu P, Wu H, Zhang Z and Tang Z: Multiple molecular targets in breast cancer therapy by betulinic acid. Biomed Pharmacother 84: 1321-1330, 2016.

7 Pavel S, Alzbeta F, Alena T, Mohamed N, Ales B and Havelek $\mathrm{R}$ : Effective method of purification of betulin from birch bark: The importance of its purity for scientific and medicinal use. Plos One 11(5): e0154933, 2016.

8 Sheng $\mathrm{H}$ and Sun H: Synthesis, biology and clinical significance of pentacyclic triterpenes: A multi-target approach to prevention and treatment of metabolic and vascular diseases. Nat Prod Rep 42(27): 543-593, 2011.

9 Eckerman $\mathrm{C}$ and Ekman R: Comparison of solvents for extraction and crystallization of betulinol from birch bark waste. PapPuu-pap Tim 67(3): 100-106, 1985.

10 Alakurtti S, Mäkelä T and Koskimies S, Yli-Kauhaluoma J: Pharmacological properties of the ubiquitous natural product betulin. Eur J PharmSci 29(1): 1-13, 2006.

11 Gautam R and Jachak SM: Recent developments in antiinflammatory natural products. Med Res Rev 29: 767-820, 2009.

12 Lin CK, Tseng CK, Chen KH, Wu SH, Liaw CC and Lee JC: Betulinic acid exerts anti-hepatitis $\mathrm{C}$ virus activity via the suppression of NF-kB and MAPK-ERK1/2-mediated cyclooxygenase-2 expression. Brit J Pharmacol 172(18): 4481-4492, 2015.

13 Lingaraju MC, Pathak NN, Begum J, Balaganur V, Bhat RA, Ramachandra HD, Ayanur A, Ram M, Singh V, Kumar D and Tandan SK: Betulinic acid attenuates lung injury by modulation of inflammatory cytokine response in experimentally-induced polymicrobial sepsis in mice. Cytokine 71(1): 101-108, 2015.

14 Hwang BY, Chai HB, Kardono LB, Riswan S, Farnsworth NR, Cordell GA, Pezzuto JM and Kinghorm AD: Cytotoxic triterpenes from the twigs of Celtisphilippinensis. Phytochem Lett 62(2): 197-201, 2003.

15 Simone F: Betulinic acid for cancer treatment and prevention. Int J Mol Sci 9(6): 1096-1107, 2008.

16 Shunichi W, Akira Iida A and Tanaka R: Screening of triterpenoids isolated from phyllanthus flexuosus for DNA topoisomerase inhibitory activity. J Nat Prod 64(12): 1545-1547, 2001.

17 Beretta GL, Perego P and Zunino F: Targeting topoisomerase I: molecular mechanisms and cellular determinants of response to topoisomerase I inhibitors. Expert Opin Ther Tar 12(10): 12431256, 2008.

18 Momoi Y, Okai Y, Watari T, Goitsuka R, Tsujimoto H and Haswfawa A: Establishment and characterization of a canine Tlymphoblastoid cell line derived from malignant lymphoma. Vet Immunol Immunopathol 59: 11-20, 1997.
19 Ruegen BC, Hammer SE, Gerner W, Christian M, de Arespacochaga AG, Willmann M, Kleiter M, Schwendenwein I and Saalmuller A: Establishment and characterization of a novel canine derived from a spontaneously occurring diffuse large cell lymphoma. Leuk Res 34: 932-938, 2010.

20 Pawlak A, Kutkowska J, Obmińska-Mrukowicz B and Rapak A: Methotrexate induces high level of apoptosis in canine lymphoma/leukemia cell lines. Res Vet Sci 114: 518-523, 2017.

21 Orchel A, Kulczycka A, Chodurek E, Bebenek E, Borkowska P, Boryczka S, Kowalski J and Dzierzewicz Z: Influence of betulin and 28-O-propynoylbetulin on proliferation and apoptosis of human melanoma cells (G-361). Postępy Hig Med Dosw 68: 191-197, 2014

22 Fulda S, Scaffidi C, Susin SA, Krammer PH, Kroemer G, Peter $\mathrm{ME}$ and Debatin KM: Activation of mitochondria and release of mitochondrial apoptogenic factors by betulinic acid. J Biol Chem 273(51): 33942-33948, 1998.

23 Schmidt ML, Kuzmanoff KL, Ling-Indeck L and Pezzuto JM: Betulinic acid induces apoptosis in human neuroblastoma cell lines. Eur J Cancer 33(12): 2007-2010, 1997.

24 Zuco V, Supino R, Righetti S C, Cleris L, Marchesi E, Gambacorti-Passerini C and Formelli F: Selective cytotoxicity of betulinic acid on tumor cell lines, but not on normal cells. Cancer Lett 175(1): 17-25, 2002.

25 Fulda S, Jeremias I, Steiner HH, Pietsch T and Debatinn KM: Betulinic acid: A new cytotoxic agent against malignant braintumor cells. Int J Cancer 82(3): 435-441, 1999.

26 Henklewska M, Pawlak A, Pruchnik H and Obmińska-Mrukowicz B: Complex of platinum(II) with tris(2-carboxyethyl) phosphine induces apoptosis in canine lymphoma/ leukemia cell lines. Anticancer Res 37(2): 539-546, 2017.

27 Rzeski W, Stepulak A, Szymański M, Juszczak M, Grabarska A, Sifringer M, Kaczor J and Kandefer-Szerszen M: Betulin elicits anti-cancer effects in tumour primary cultures and cell lines in vitro. Basic Clin Pharmacol 105(6): 425-432, 2009.

$28 \mathrm{Xu} \mathrm{T}$, Pang Q, Wang Y and Yan X: Betulinic acid induces apoptosis by regulating PI3K/Akt signaling and mitochondrial pathways in human cervical cancer cells. Int J Mol Med 40(6): 1669-1678, 2017.

29 Drąg-Zalesińska M, Drąg M, Poręba M, Borska S, Kulbacka J and Saczko J: Anticancer properties of ester derivatives of betulin in human metastatic melanoma cells (Me-45). Cancer Cell Int 17(1): 4-10, 2017.

30 Ciurlea SA, Dehelean CA, Ionescu D, Berko S, Csanyi E, Hadaruga DI, Ganta S and Amiji MM: A comparative study regarding melanoma activity of betulinic acid on topical ointment vs. systemic nanoemulsion delivery systems. Agroaliment Process Technol 16: 420-426, 2010.

31 Fulda S and Debatin K: Betulinic acid induces apoptosis through a direct effect on mitochondria in neuroectodermal tumors. Med Pediatr Oncol 35(6): 616-618, 2000.

$32 \mathrm{Li} \mathrm{Y,} \mathrm{He} \mathrm{K,} \mathrm{Huang} \mathrm{Y,} \mathrm{Zheng} \mathrm{D,} \mathrm{Gao} \mathrm{C,} \mathrm{Gui} \mathrm{L} \mathrm{and} \mathrm{Jin} \mathrm{Y:} \mathrm{Betulin}$ induces mitochondrial cytochrome $\mathrm{c}$ release associated apoptosis in human cancer cells. Mol Carcinogen 49(7): 630-640, 2001.

33 Kim DS, Pezzuto JM and Pisha E: Synthesis of betulinicacid derivatives with activity against human melanoma. Bioorg Med Chem Lett 8(13): 1707-1712, 1998.

34 Selzer E, Pimentel E, Wacheck V, Schleqel W, Pehamberger H, Jansen B and Kodym R: Effects of betulinic acid alone and in 
combination with irradiation in human melanoma cells. J Invest Dermatol 114(5): 935-940, 2000.

35 Salti G I, Kichina J V, Das Gupta T K, Uddin S, Bratescu L, Pezzuto JM, Mehta RG and Constantinou AI: Betulinic acid reduces ultraviolet-C-induced DNA breakage in congenital melanocytic naeval cells: evidence for a potential role as a chemopreventive agent. Melanoma Res 11(2): 99-104, 2001.

36 Yao N, Li Y, Lei Y, Hu N, Chen W, Yao Z, Yu M, Liu J, Ye W and Zhang D: A piperazidine derivative of 23-hydroxy betulinic acid induces a mitochondria-derived ROS burst to trigger apoptotic cell death in hepatocellular carcinoma cells. J Exp Clin Cancer Res 35(1): 192-206, 2016.

$37 \mathrm{Li} \mathrm{J}$ and Wei J: Studies on arsenic trioxide induces apoptosis in hepatoma cell lines Bel-7402. Chin J Cancer 19(12): 1087-1091, 2000.

38 Zhou R, Zhang Z, Zhao L, Jia C, Xu S, Mai Q, Lu M, Huang $M$, Wang L, Wang X, Jin D and Bai X: Inhibition of mTOR signaling by oleanolic acid contributes to its anti-tumor activity in osteosarcoma cells. J Orthop Res 29(6): 846-852, 2011.

39 Tan GT, Lee S, Lee IS, Chen J, Leitner P, Besterman JM, Kinghorn $\mathrm{AD}$ and Pezzuto JM: Natural-product inhibitors of human DNA ligase I. Biochem J 314(Pt 3): 993-1000, 1996.
$40 \mathrm{Xu} \mathrm{T}$, Pang Q, Wang Y and Yan X: Betulinic acid induces apoptosis by regulating PI3K/Akt signaling and mitochondrial pathways in human cervical cancer cells. Int J Mol Med 40(6): 1669-1678, 2017.

41 Foo JB, Yazan LS, Yin ST, Wibowo A, Ismail N, How CW, Armania N, Loh S, Ismail IS, Chenh YK and Abdullah R: Induction of cell cycle arrest and apoptosis by betulinic acid-rich fraction from Dillenia suffruticosa, root in MCF-7 cells involved p53/p21 and mitochondrial signalling pathway. J Ethnopharmacol 166: 270-278, 2015.

42 Yadav VR, Sahdeo P, Bokyung S, Ramaswamy K and Aggarwal BB: Targeting inflammatory pathways by triterpenoids for prevention and treatment of cancer. Toxins 2(10): 2428-2466, 2010.

Received April 19, 2018

Revised May 28, 2018

Accepted June 4, 2018 